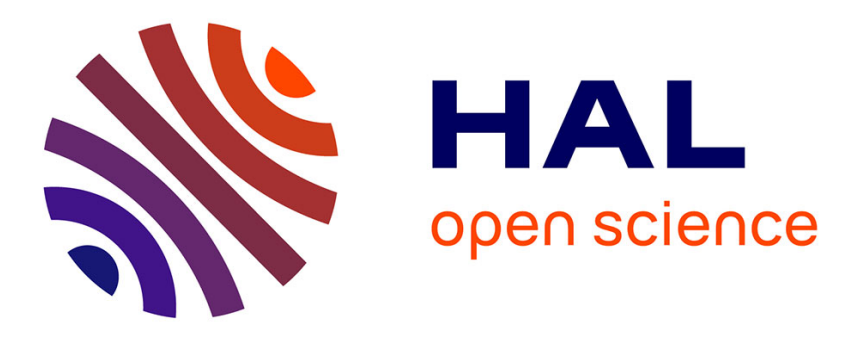

\title{
Novel mutations in TTC37 associated with Tricho-Hepato-Enteric syndrome
}

Alexandre Fabre, Christine Martinez-Vinson, Bertrand Roquelaure, Chantal Missirian, Nicolas Andre, Anne Breton, Alain Lachaux, Odul Egritas, Virginie Colomb, Julie Lemale, et al.

\section{To cite this version:}

Alexandre Fabre, Christine Martinez-Vinson, Bertrand Roquelaure, Chantal Missirian, Nicolas Andre, et al.. Novel mutations in TTC37 associated with Tricho-Hepato-Enteric syndrome. Human Mutation, 2011, 32 (3), pp.277. 10.1002/humu.21420 . hal-00614846

\section{HAL Id: hal-00614846 \\ https://hal.science/hal-00614846}

Submitted on 17 Aug 2011

HAL is a multi-disciplinary open access archive for the deposit and dissemination of scientific research documents, whether they are published or not. The documents may come from teaching and research institutions in France or abroad, or from public or private research centers.
L'archive ouverte pluridisciplinaire HAL, est destinée au dépôt et à la diffusion de documents scientifiques de niveau recherche, publiés ou non, émanant des établissements d'enseignement et de recherche français ou étrangers, des laboratoires publics ou privés. 


\section{Human Mutation}

WILEY

\section{Novel mutations in TTC37 associated with Tricho-Hepato- Enteric syndrome}

\begin{tabular}{|c|c|}
\hline Journal: & Human Mutation \\
\hline Manuscript ID: & humu-2010-0401.R1 \\
\hline Wiley - Manuscript type: & Research Article \\
\hline $\begin{array}{r}\text { Date Submitted by the } \\
\text { Author: }\end{array}$ & 04-Oct-2010 \\
\hline Complete List of Authors: & $\begin{array}{l}\text { Fabre, Alexandre; Hôpital d'enfants de la Timone, Service de } \\
\text { Pédiatrie Multidisciplinaire } \\
\text { Martinez-Vinson, Christine; Hôpital Robert Debré, Centre de } \\
\text { Référence pour les Maladies Digestives Rares de l'enfant, APHP, } \\
\text { Gastroentérologie et Nutrition Pédiatrique } \\
\text { Roquelaure, Bertrand; hôpital d'enfants de la Timone, Service de } \\
\text { pédiatrie multidiciplinaire } \\
\text { Missirian, Chantal; Hôpital d'enfants de la Timone, Laboratoire de } \\
\text { Cytogénétique } \\
\text { Andre, Nicolas; Hôpital d'enfants de la Timone, Service d'oncologie } \\
\text { pédiatrique } \\
\text { Breton, Anne; Hôpital des Enfants, Gastro-entérologie, Hépatologie, } \\
\text { Nutrition, Diabétologie } \\
\text { Lachaux, Alain; hôpital Femme-Mère-Enfant du CHU de Lyon, } \\
\text { Hepatologie Gastroentérologie et Nutrition } \\
\text { Egritas, Odul; Gazi University School of Medicine, Department of } \\
\text { Pediatric Gastroenterology } \\
\text { Colomb, Virginie; Hôpital Necker-Enfants Malades, Centre de } \\
\text { Référence pour les Maladies Digestives Rares de l'enfant, APHP, } \\
\text { Gastroentérologie et Nutrition Pédiatrique } \\
\text { Lemale, Julie; Hôpital Armand Trousseau, APHP, Gastroentérologie } \\
\text { et Nutrition Pédiatrique } \\
\text { Cezard, Jean-Pierre; Hôpital Robert Debré, Centre de Référence } \\
\text { pour les Maladies Digestives Rares de l'enfant, APHP, } \\
\text { Gastroentérologie et Nutrition Pédiatrique } \\
\text { Goulet, Olivier; Hôpital Necker-Enfants Malades, Centre de } \\
\text { Référence pour les Maladies Digestives Rares de l'enfant, APHP, } \\
\text { Gastroentérologie et Nutrition Pédiatrique } \\
\text { Sarles, Jacques; hôpital d'enfants de la Timone, Service de } \\
\text { pédiatrie multidisciplinaire } \\
\text { Levy, Nicolas; UMR 910, Faculté de médecine, université de la } \\
\text { Méditerranée } \\
\text { Badens, Catherine; UMR 910, Faculté de Médecine, Université de la } \\
\text { Méditerranée }\end{array}$ \\
\hline
\end{tabular}


Syndromic diarrhea, Tricho-hepato-enteric syndrome, TTC37, intractable diarrhea, Woolly hair, Thespin, Stankler syndrome

\section{SCHOLARONE ${ }^{\text {m }}$ \\ Manuscripts}


Novel mutations in TTC37 associated with Tricho-Hepato-Enteric syndrome

\begin{abstract}
Alexandre Fabre ${ }^{1,2}$, Christine Martinez-Vinson ${ }^{3}$, Bertrand Roquelaure ${ }^{1}$, Chantal Missirian ${ }^{4}$, Nicolas André ${ }^{5}$, Anne Breton ${ }^{6}$, Alain Lachaux ${ }^{7}$, Egritas Odul ${ }^{8}$, Virginie Colomb ${ }^{9}$, Julie Lemale $^{10}$, Jean-Pierre Cézard ${ }^{3}$, Olivier Goulet ${ }^{9}$, Jacques Sarles ${ }^{1}$, Nicolas Levy ${ }^{2,11}$, Catherine Badens $^{2,11}$.
\end{abstract}

1 Service de Pédiatrie Multidisciplinaire, 2 Laboratoire de Génétique Moléculaire, Hôpital d'enfants de la Timone, Marseille, 3 Service de Gastro-entérologie, Hôpital Robert Debré, Paris, 4 Laboratoire de cytogénétique, Hôpital d'enfants de la Timone, Marseille, 5 Service de Pédiatrie Oncologique, Hôpital d'enfants de la Timone, Marseille, 6 Service d'Hépatologie et Maladies Métaboliques, Hôpital d'enfant de Toulouse, 7 Unité Fonctionnelle de Nutrition, Hôpital Femme Mère Enfant de Lyon, 8 Gazi University School of Medicine, Department of Pediatric Gastroenterology, Ankara, Turkey, 9 Service de Gastro-entérologie, Hôpital NeckerEnfants Malades, Paris, 10 Gastroentérologie et Nutrition Pédiatrique, Hôpital Armand Trousseau, Paris, 11 Unité Inserm U910, Faculté de Médecine, Université de la Méditerranée, Marseille, France.

Key words: Syndromic Diarrhea, Intractable diarrhea, Tricho-Hepato-Enteric syndrome, Stankler syndrome, TTC37, woolly hair,

Corresponding author :

Dr Catherine Badens

Laboratoire de Génétique moléculaire

Département de Génétique

Hôpital de la Timone

13385 Marseille cedex 5

France 


\begin{abstract}
The Tricho-Hepato-Enteric (THE) syndrome is an autosomal recessive condition marked by $\underline{\text { early and intractable diarrhea, hair abnormalities and immune defects. Mutations in TTC37 }}$ which encodes the putative protein Thespin, have recently been associated with THE syndrome. In this paper, we extend the pattern of TTC37 mutations by the description of 11 novel mutations in 9 patients with a typical THE syndrome. The mutations were spread along the gene sequence, none of them being recurrent. Different types of mutation were observed: $\underline{\text { frameshift mutations, splice site altering mutations or missense mutations, most of them }}$ leading to the creation of a premature stop codon. Concurrently, we investigated the pattern of

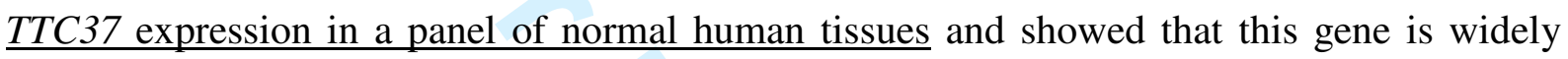
expressed, with high levels in vascular tissues, lymph node, pituitary, lung and intestine. In contrast, TTC37 is not expressed in the liver, an organ which is not consistently affected in THE syndrome. Lastly, we suggested a model for the putative structure of the unknown Thespin protein.
\end{abstract}




\section{Introduction}

$\underline{\text { The Tricho-Hepato-Enteric syndrome (THE syndrome, OMIM n²22470) also known as }}$ $\underline{\text { Syndromic Diarrhea, is a rare and severe autosomal recessive condition which associates }}$ intractable diarrhea with facial dysmorphism, intrauterine growth retardation, immunodeficiency with low serum concentrations of immunoglobulins, and hair abnormalities characterized by woolly hair (Girault et al., 1994; Verloes et al., 1997). Parenteral nutrition is usually started in the first weeks of life and maintained all life long in most cases. The liver failure is inconstant and when present, it is observed initially or later on in life. In the past, the presence or absence of liver failure led one to describe 2 different syndromes but it is now admitted that the 2 entities represent 2 sides of the same disease (Fabre et al, 2007, Goulet et al, 2008). Death can occur early in life even though some patients can reach the third decade.

In the past few years, we collected samples for 12 patients from 11 families, all presenting a typical phenotype of THE syndrome. We first excluded several functional candidate genes (Fabre et al, 2009) and then performed a linkage analysis in order to unravel the genetic basis of this syndrome. In 2 of the 3 consanguineous families, homozygosity mapping identified a $5 \mathrm{Mb}$ region in $5 \mathrm{q}$ as a potential locus for the disease.

Very recently, Hartley et al described molecular defects causative for THE syndrome in

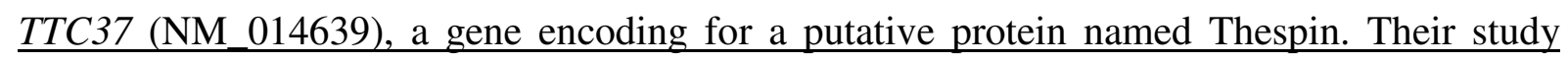
reported 9 mutations transmitted in a recessive pattern in 12 patients presenting this syndrome.

Since TTC37 maps in 5q, we assumed that this gene may be responsible for the disease in some of our patients and so performed systematic sequencing of genomic DNA samples. In this paper, we describe 11 novel TTC37 mutations in 9 patients out of 12 and provide clinical 


\section{Material and methods:}

\section{Patients}

Patients and family members were assessed under approved human subject protocols and all participants provided informed consent.

\section{Molecular studies}

DNA was isolated from blood via a standard manufacturer's protocol (QIAamp DNA blood minikit, QIAgen). To analyse the TTC37 gene, direct sequencing was performed, after PCR amplification of the 43 exons and intronic flanking sequences, on an ABI 3130XL (Applied Biosystems).

The TTC37 genomic sequence from GenBank accession numbers NM_014639 was used as reference sequence. Detailed protocols and primer sequences are available on request. Two non-mutated patients and one heterozygous were tested by CGH array using the commercial Agilent 2x400K SurePrint G3 Human CGH Microarray (Agilent Technologies) array with the overall median probe spacing of 5,3 $\mathrm{kb}$. Total RNA from 3 patient samples was prepared from lymphoblastoid cells and reverse transcribed using M-MLV (Sygma). Normal expression pattern was investigated by $\mathrm{qPCR}$ on a panel of normal transcripts from various tissues (Rapid-Scan cDNA panel, OriGene) using a probe located on exon-intron junction 35-36 of TTC37 and compared to GAPDH expression in duplex reactions. qPCR were done in triplicates and 2 sets of experiments were performed.

\section{Bioinformatics analysis}

The topology of normal and mutated Thespin protein was analysed using the algorithms proposed at TMpred (http://www.ch.embnet.org/software/TMPRED_form.html), TOPPRED 
(http://www.mobyle.pasteur.fr/cgi-bin/portal.py?form=Toppred),

PSORT

II

(http://psort.ims.u-tokyo.ac.jp) and SMART (http://smart.embl.de/smart/show_motifs.pl)

Predicted effects of missense mutations were obtained on Polyphen website (http://genetics.bwh.harvard.edu/pph).

\section{Results}

\section{Patients phenotype}

The clinical features of the 12 patients are summarised in table 1. Detailed clinical data were previously published for 3 of them (Fabre et al, 2007, Egritas et al 2010). All the 12 patients presented the 3 major signs of THE syndrome i.e. dysmorphism, hair abnormalities and intractable diarrhea. Among the 12 patients, one died of septicemia at age 10, 2 have stopped parenteral nutrition and 1 never required it.

\section{Identification and characterization of novel TTC37 mutations in THE patients}

Screening for mutations of TTC37 coding sequence and intron-exon junctions of DNA samples from THE patients identified 10 novel non ambiguous mutations in homozygous or compound heterozygous condition, in 8 (out of 12) patients. In addition, one patient presented only a heterozygous missense mutation. The mutations were spread along the gene: 3 were nonsense or frameshift mutations in the coding sequence leading to premature stop codon, 5 were mutations affecting splice sites either by substitution or deletion and 3 were missense mutations. All the parents of mutated patients were investigated and carried a mutation in heterozygous condition. The location and predicted consequences of the mutations on protein expression or function are reported in table 2.

Two of the 3 patients without mutation and the one with a single heterozygous mutation were investigated by whole genome CGH array with 17 probes mapping in TTC37. No CNV of the TTC37 region or of other regions could be identified. 


\section{1}

The effects of splice sites mutations on sequence transcripts were analysed by direct sequencing of RNA transcripts from lymphoblastoid cells, for 3 patients. The tested samples exhibited abnormal sequence due to the modification of splicing: skipping exon 23 in the case of the c.2515+1 $\mathrm{C}>\mathrm{G}$ mutation, leading to a frameshift and creation of a premature stop codon (figure 1a); skipping exon 25 in the case of the c.2577-3_-7delTTTT, leading to the deletion of 19 amino-acids in frame (figure 1b); cryptic splice activation in exon 42 in case of the $c .4620+1 \mathrm{G}>\mathrm{C}$ mutation promoting an alternative splicing and the replacement of the 41 terminal amino-acids by 61 others.

\section{Pattern of expression}

Quantitative expression in normal tissues was assessed in a panel of 48 different tissues and revealed that TTC37 is widely expressed with the highest levels observed in vascular tissues, lymph node, pituitary, lung and intestine. Noticeably, we did not find any expression in the liver (figure 2).

\section{Bioinformatics}

In silico protein predictions were performed to propose a putative structure for Thespin and to evaluate the potential effect of TTC37 mutations identified in this study. The algorithm results are in accordance to predict that Thespin is mostly cytosolic and may contain 4 transmembrane domains (Figure 3). With all algorithms used in this study, several tetratricopeptide repeats (TPR) domains are predicted and their number varies from 5 to 22 .

\section{Discussion}

Mutations previously identified in THE syndrome are heterogeneous and include frameshift, nonsense and splice site mutations. Here, we describe further 11 different mutations that add heterogeneity to the molecular genetics of THE syndrome (figure 3). These 11 novel mutations, in addition to the 9 mutations previously described, indicate strongly that TTC37 is the main gene responsible for THE syndrome. There is no clear hot spot region for mutations 
even though, in $70 \%$ of the mutated alleles (Hartley et al 2010 and our study), the mutation is localised in the 3' half of the gene. Most of the mutations are nonsense, frameshift or splice mutations that are predicted to produce premature stop codon. At least, 2 of the 3 missense mutations might affect splicing as well, as they are located in the vicinity of splice sites. For one of the patients, a single missense mutation in heterozygous condition has been identified to date. As we exclude the presence of an intragenic deletion or duplication on the other allele, we assume that a non-identified intronic substitution producing an aberrant splicing is probably associated with the missense mutation.

The phenotypes of the 3 patients who did not carry any mutation in TTC37 have been carefully re-evaluated and were confirmed as being typical THE syndrome, suggesting strongly that at least one other gene may be implicated in this disease.

Multi-tissue transcript expression analysis showed wide expression of TTC37 mRNA with a high expression level in intestinal tissue but not in the liver, indicating that liver dysfunction observed in THE syndrome is probably secondary to another genetic cause or to long term parenteral nutrition. More surprising is the high level of expression observed in vein, arteria and lung as no abnormalities have been noticed in these tissues.

Up to date, the function of Thespin is unknown. We identified orthologs of human TTC37 using HomoloGene (www.ncbi.nlm.nih.gov/homologene) and found a nucleotide sequence conservation in canis $(92 \%)$, bos $(92 \%)$, rattus $(83 \%)$, mus $(82 \%)$, gallus $(66 \%)$, danio $(55 \%)$ and drosophila $(27 \%)$ in favour of an essential role for Thespin.

Protein motifs and domains are predicted in Thespin by several algorithms such as TMpred, PSORT and TOPPRED. Four transmembrane domains located in the C-terminal half of the protein are predicted, the last one in the $\mathrm{C}$-terminal part being predicted with a stronger score. The putative protein also contains several tetratrico-peptide repeats (TPR) domains which are structural motifs consisting of 34 Amino acid residues and found in over 300 human proteins 
(D'andrea et al, 2003). Despite the fact that the amino-acids are poorly conserved, these motifs assemble into a characteristic Helix-Turn-Helix structure. The basic function of these TPR motifs is to mediate protein-protein interactions and therefore, can be involved in a variety of biological process such as cell-cycle regulation, transcriptional control, protein transport or folding. Consequently, no hint is given by the presence of TPR domains regarding a specific function. Interestingly, one of the splice site mutations of this series leads to a deletion of 19 residues in frame, following the skipping of exon 25 . This deletion does not modify the predicted transmembrane domains but deleted several putative TPR domains of the C-terminal part, suggesting a major functional role for these structures.

Beside the TPR domains, neither the gene nor its derived protein show any significant sequence similarity to other known human DNA or protein sequences. In the literature, mutations in other TPRs containing proteins have been described as causative in several neurological human diseases such as Leber congenital amaurosis (Sohocki et al, 2000) or CMT type 4C (Senderek et al, 2003) but no clear link can be made between these proteins and their putative function.

Collectively, our results confirmed the role of TTC37 in THE syndrome, extended the pattern of mutations associated with this syndrome and provided new data on the normal expression pattern of TTC37 and the putative structure of Thespin. Assigning an unknown protein to a specific disease as done for THE syndrome, may enable one to describe new protein functions and will lead surely to characterize the localisation and functional properties of Thespin.

\section{Acknowledgements}

We are grateful to the patients and family members for their participation in the study and warmly acknowledge Patrice Bourgeois, Pierre Cau and Claudine Schiff for their helpful discussion, Benedicte Arnaud-Pigneur and Noël Peretti for providing patient samples. This work was supported by the Assistance Publique-Hôpitaux de Marseille (AORC 2009). 


\section{References}

D'Andrea LD, Regan L. 2003. TPR proteins: the versatile helix. Trends Biochem Sci. 28(12):655-62.

Egritas O, Dalgic B, Onder M Tricho-hepato-enteric syndrome presenting with mild colitis. 2009 Eur J Pediatr. 168(8):933-5.

Fabre A, Andre N, Breton A, Broué P, Badens C, Roquelaure B. 2007. Intractable diarrhea with "phenotypic anomalies" and tricho-hepato-enteric syndrome: two names for the same disorder. Am J Med Genet A. 143(6):584-8.

Fabre A, Roquelaure B, Lacoste C André N, Sarles J, Breton A, Martinez-Vinson C, Cezard JP, Colomb V, Goulet O, Levy N, Badens C. 2009. Exclusion of EGFR, HRAS, DSP, JUP, CTNNB1, PLEC1 and EPPK1 as functional candidate genes in 7 families with Syndromic Intractable Diarrhea. J Pediatr Gastroenterol Nutr. 48(4):501-3.

Girault D, Goulet O, Le Deist F, Brousse N, Colomb V, Cesarini JP, de Potter S, Canioni D, Griscelli C, Fischer A. 1994 Intractable infant diarrhea associated with phenotypic abnormalities and immunodeficiency. J Pediatr. 125:36-42.

Goulet O, Vinson C, Roquelaure B, Brousse N, Bodemer C, Cézard JP. 2008. Syndromic (phenotypic) diarrhea in early infancy. Orphanet J Rare Dis. 28;3:6.

Hartley JL, Zachos NC, Dawood B, Donowitz M, Forman J, Pollitt RJ, Morgan NV, Tee L, Gissen P, Kahr WH, Knisely AS, Watson S, Chitayat D, Booth IW, Protheroe S, Murphy S, de Vries E, Kelly DA, Maher ER. 2010. Mutations in TTC37 cause trichohepatoenteric syndrome (phenotypic diarrhea of infancy). Gastroenterology. 138:2388-98.

Senderek J, Bergmann C, Stendel C, Kirfel J, Verpoorten N, De Jonghe P, Timmerman V, Chrast R, Verheijen MH, Lemke G, Battaloglu E, Parman Y, Erdem S, Tan E, Topaloglu H, Hahn A, Müller-Felber W, Rizzuto N, Fabrizi GM, Stuhrmann M, Rudnik-Schöneborn S, Züchner S, Michael Schröder J, Buchheim E, Straub V, Klepper J, Huehne K, 

4 5

Rautenstrauss B, Büttner R, Nelis E, Zerres K. 2003. Mutations in a gene encoding a novel SH3/TPR domain protein cause autosomal recessive Charcot-Marie-Tooth type 4C neuropathy. Am J Hum Genet. 73:1106-19.

Sohocki MM, Bowne SJ, Sullivan LS, Blackshaw S, Cepko CL, Payne AM, Bhattacharya SS, Khaliq S, Qasim Mehdi S, Birch DG, Harrison WR, Elder FF, Heckenlively JR, Daiger SP. 2000. Mutations in a new photoreceptor-pineal gene on $17 \mathrm{p}$ cause Leber congenital amaurosis. Nat Genet. 24:79-83.

Verloes A, Lombet J, Lambert Y, Hubert AF, Deprez M, Fridman V, Gosseye S, Rigo J, Sokal E. 1997. Tricho-Hepato-Enteric Syndrome: Further Delineation of a Distinct Syndrome With Neonatal Hemochromatosis Phenotype, Intractable Diarrhea, and Hair Anomalies. Am J Med Genet. 68:391-395. 
Legends

Figure 1:

Sequencing analysis of transcripts in 2 patients with splice mutations:

a: scheme representation of the splice site mutation c.2515+1 C>G, cDNA PCR amplification with primers located in exon 22 and 24 for the homozygous patient, his heterozygous mother and a normal control and sequence obtained for the patient showing exon 23 skipping. b: scheme representation of the splice site mutation c.2577-3_-7delTTTTT, cDNA PCR amplification with primers located in exon 23 and 26 for the homozygous patient and a normal control and sequence (forward and reverse) obtained for the patient showing exon 25 skipping.

Figure 2:

qPCR analysis on normal human tissues: 48 tissues have been tested, 34 are shown on the graph. Experiments have been done twice with probe located on exons 35-36 junction. RQ: Relative Quantification to GAPDH expression.

Figure 3:

a: Scheme representation of TTC37 with mutations described previously (underneath) and in our study (above); red: non sense or frameshift, blue missense, green: splicing mutations. b: Model of human Thespin as predicted by TMPred algorithm. 


\begin{tabular}{|l|l|l|l|}
\hline & \multicolumn{1}{|c|}{$\begin{array}{c}\text { Patients with } \\
\text { mutations in } \\
\text { TTC37 }\end{array}$} & \multicolumn{1}{|c|}{$\begin{array}{c}\text { Patients without } \\
\text { mutations in }\end{array}$} & TTC37 \\
\hline Number of patients (families) & $9(8)$ & $3(3)$ & $12(11)$ \\
Consanguinity & $4 / 8$ & $1 / 3$ & $7 / 11$ \\
Median age & $10 \mathrm{y}$ & 11 y 2010 \\
Male/female & $4 / 5$ & $0 / 3$ & $3 \mathrm{y}$ \\
Hair abnormalities & $9 / 9$ & $3 / 3$ & $6 / 6$ \\
Dysmorphism & $9 / 9$ & $3 / 3$ & $12 / 12$ \\
Intractable diarrhea & $9 / 9$ & $3 / 3$ & $12 / 12$ \\
Onset in the first month & $7 / 9$ & $2 / 3$ & $12 / 12$ \\
Parenteral nutrition & $9 / 9$ & $2 / 3$ & $\mathrm{NR}$ \\
Immunodeficiency & $9 / 9$ & $2 / 3$ & $12 / 12$ \\
IUGR & $7 / 9$ & $2 / 3$ & $12 / 12$ \\
Weight<3percentile & $6 / 9$ & $2 / 3$ & $10 / 11$ \\
Liver involvement & $4 / 9$ (initial 1/4) & $2 / 3$ (initial 2/3) & $5 / 10$ \\
Mental retardation & $5 / 8$ & $2 / 3$ & $7 / 9$ \\
& & & \\
\hline
\end{tabular}

Table 1:

Clinical features of the 12 patients of this study and the 12 previously published by Hartley et al, 2010. Facial dysmorphism is characterized by hypertelorism, broad flat nasal bridge, prominent forehead; Observed hair abnormalities are sparse, fragile and uncombable hair with $\underline{\text { trichorrhexis nodosa. NR: not reported }}$ 
Table 2. Mutations in TTC37, geographical origin and consanguinity in the families of the patients with THE syndrome (NM_014639; NP_055454)

\begin{tabular}{|c|c|c|c|c|}
\hline $\begin{array}{c}\text { Family } \\
\text { identifier } \\
\text { (number of } \\
\text { affected } \\
\text { individuals) }\end{array}$ & Mutation 1 & Mutation 2 & Consanguinity & $\begin{array}{l}\text { Geographical } \\
\text { origin }\end{array}$ \\
\hline $1(2)$ & $\begin{array}{c}\text { c.326_330delTGCCT } \\
\text { p.Leu96TrpfsX10 }\end{array}$ & $\begin{array}{c}\text { c.326_330delTGCCT } \\
\text { p.Leu96TrpfsX10 }\end{array}$ & Yes & Middle-East \\
\hline $2(1)$ & $\begin{array}{c}\text { c.1168delA } \\
\text { p.Val390PheFsX419 }\end{array}$ & $\begin{array}{c}\text { c. } 3564-2 \mathrm{~A}>\mathrm{G} \\
\text { (nd) }\end{array}$ & No & France \\
\hline $3(1)$ & $\begin{array}{c}\text { c. } 2515+1 \mathrm{G}>\mathrm{C} \\
\text { p.Cys } 813 \text { ValfsX56 }\end{array}$ & $\begin{array}{c}\text { c. } 2515+1 \mathrm{G}>\mathrm{C} \\
\text { p.Cys813ValfsX56 }\end{array}$ & Yes & North Africa \\
\hline $4(1)$ & $\begin{array}{c}\text { c.2577-3_- } \\
\text { 7DelTTTTT } \\
\text { p.Asn860_878GluDel }\end{array}$ & $\begin{array}{l}\text { c. } 4620+1 G>C \\
\text { p.Trp1524_1564 } \\
\text { DelIns61 }\end{array}$ & No & France \\
\hline $5(1)$ & $\begin{array}{l}\text { c.3015-1C>T } \\
\text { nd }\end{array}$ & $\begin{array}{c}\text { c.4454T>G } \\
\text { p.Leu1485Arg, } \\
\text { possibly damaging }\end{array}$ & No & France \\
\hline $6(1)$ & $\begin{array}{c}\text { c.3808C }>\mathrm{G} \\
\text { p.Pro1270Ala, } \\
\text { probably damaging }\end{array}$ & $\begin{array}{c}\text { c. } 3808 \mathrm{C}>\mathrm{G} \\
\text { p.Pro1270Ala, } \\
\text { probably damaging }\end{array}$ & Yes & North Africa \\
\hline $7(1)$ & $\begin{array}{l}\text { c. } 3960 C>A \\
\text { p.Tyr1320X }\end{array}$ & $\begin{array}{l}\text { c. } 3960 C>A \\
\text { p.Tyr1320X }\end{array}$ & Yes & North Africa \\
\hline $8(1)$ & $\begin{array}{c}\text { c.3230C }>\mathrm{A} \\
\text { p.Ala1077Asp, } \\
\text { probably damaging }\end{array}$ & 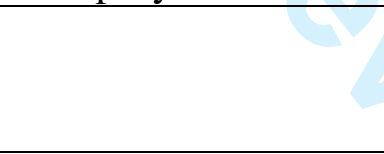 & No & France \\
\hline
\end{tabular}

Regarding missense mutations, predictions at the protein level, were done using Polyphen algorithm. For frameshift mutations, predictions are theoretical and for splice site mutations, experimental at the transcript level. Nucleotide numbering reflects cDNA numbering with +1 corresponding to the A of the ATG translation initiation codon in the reference sequence. The initiation codon is codon 1 . 

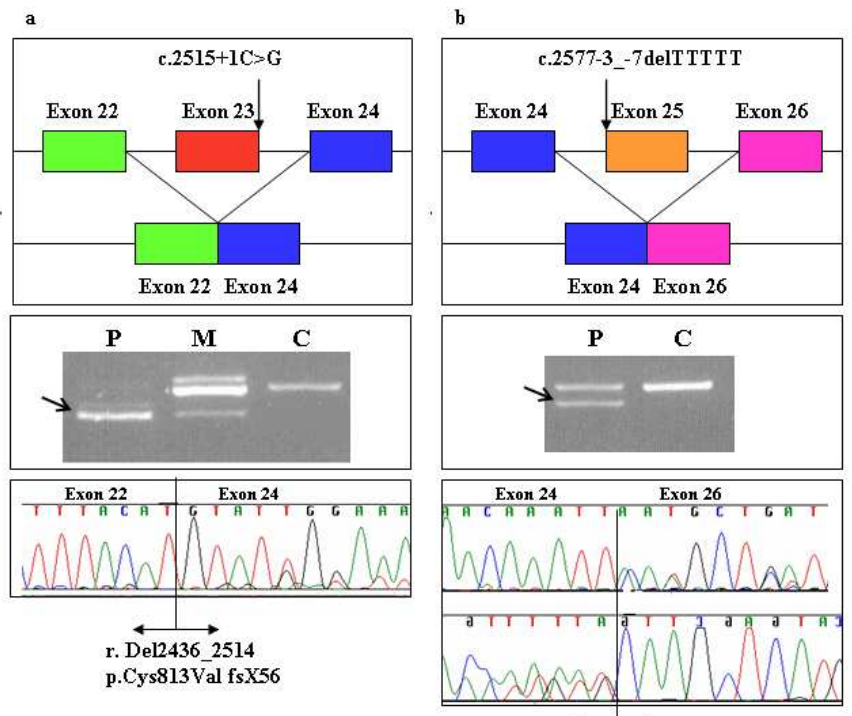

r. $\overleftrightarrow{\longleftrightarrow \text { e2578_2635 }}$

p.Asn860_878 GluDel

$254 \times 190 \mathrm{~mm}(96 \times 96$ DPI $)$

John Wiley \& Sons, Inc. 


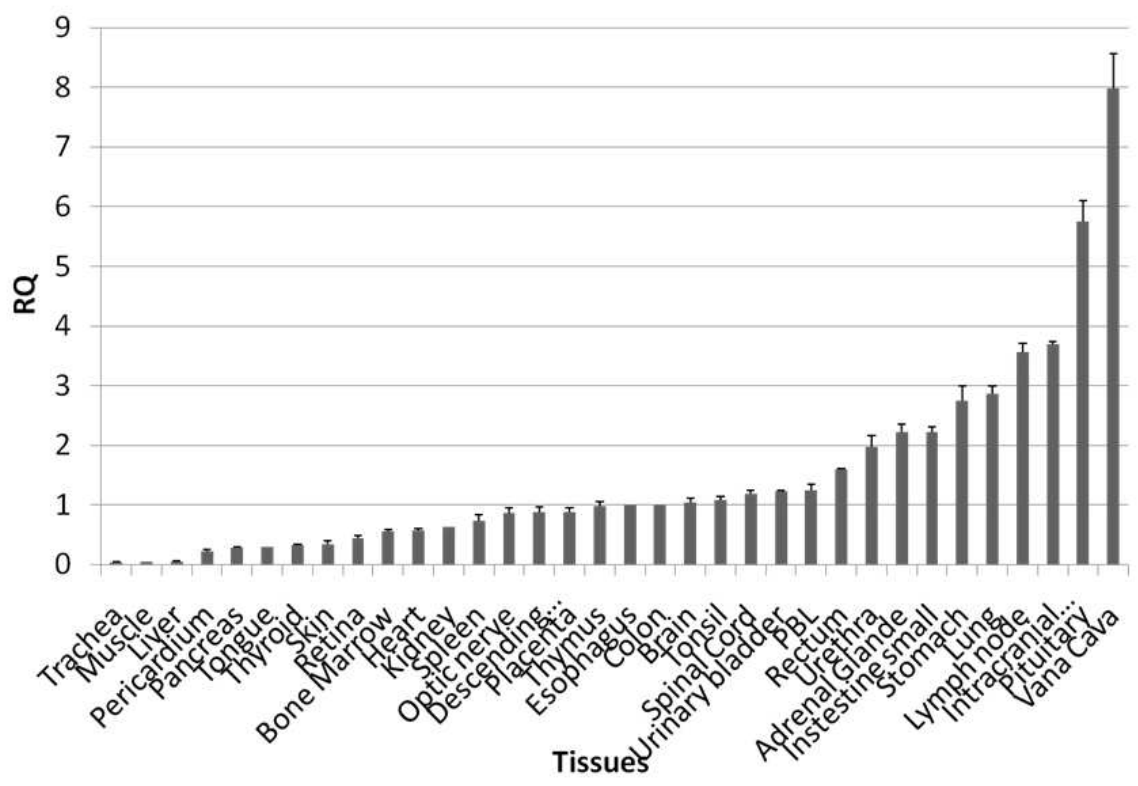

254x190mm (96 x 96 DPI)

John Wiley \& Sons, Inc. 
a

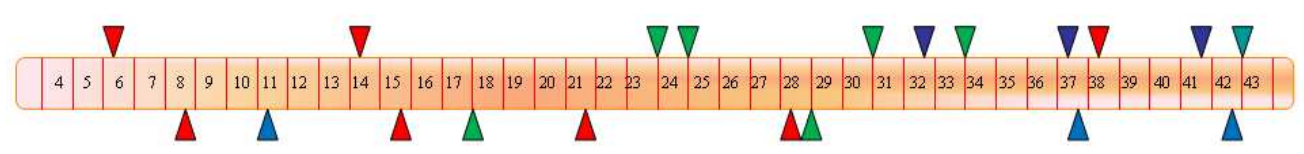

b

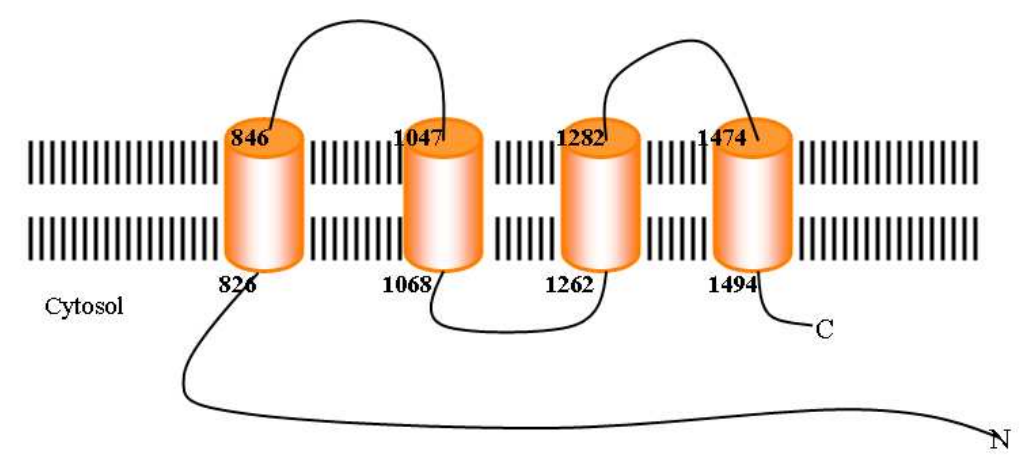

$254 \times 190 \mathrm{~mm}(96 \times 96$ DPI)

John Wiley \& Sons, Inc. 